
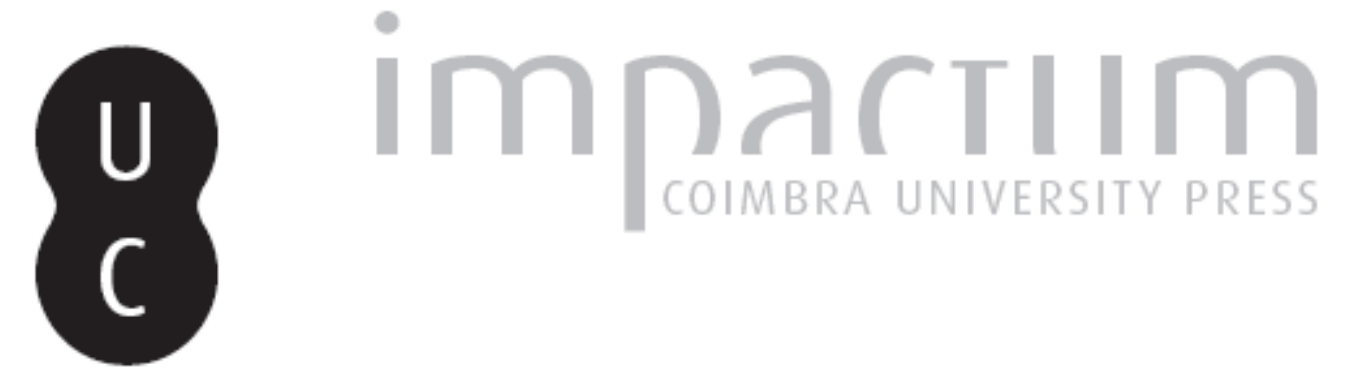

\title{
Riscos ambientais transfronteiriços e avaliação de impacte ambiental
}

Autor(es): $\quad$ Nobre, Márcio Albuquerque

Publicado por: CEDOUA

URL persistente:

URI:http://hdl.handle.net/10316.2/8848

DOI:

http://dx.doi.org/10.14195/2182-2387_23_5

Accessed : $\quad$ 26-Apr-2023 01:33:13

A navegação consulta e descarregamento dos títulos inseridos nas Bibliotecas Digitais UC Digitalis, UC Pombalina e UC Impactum, pressupõem a aceitação plena e sem reservas dos Termos e Condições de Uso destas Bibliotecas Digitais, disponíveis em https://digitalis.uc.pt/pt-pt/termos.

Conforme exposto nos referidos Termos e Condições de Uso, o descarregamento de títulos de acesso restrito requer uma licença válida de autorização devendo o utilizador aceder ao(s) documento(s) a partir de um endereço de IP da instituição detentora da supramencionada licença.

Ao utilizador é apenas permitido o descarregamento para uso pessoal, pelo que o emprego do(s) título(s) descarregado(s) para outro fim, designadamente comercial, carece de autorização do respetivo autor ou editor da obra.

Na medida em que todas as obras da UC Digitalis se encontram protegidas pelo Código do Direito de Autor e Direitos Conexos e demais legislação aplicável, toda a cópia, parcial ou total, deste documento, nos casos em que é legalmente admitida, deverá conter ou fazer-se acompanhar por este aviso. 
Doutrina

N.․․ 23 _Ano XII_1. 09

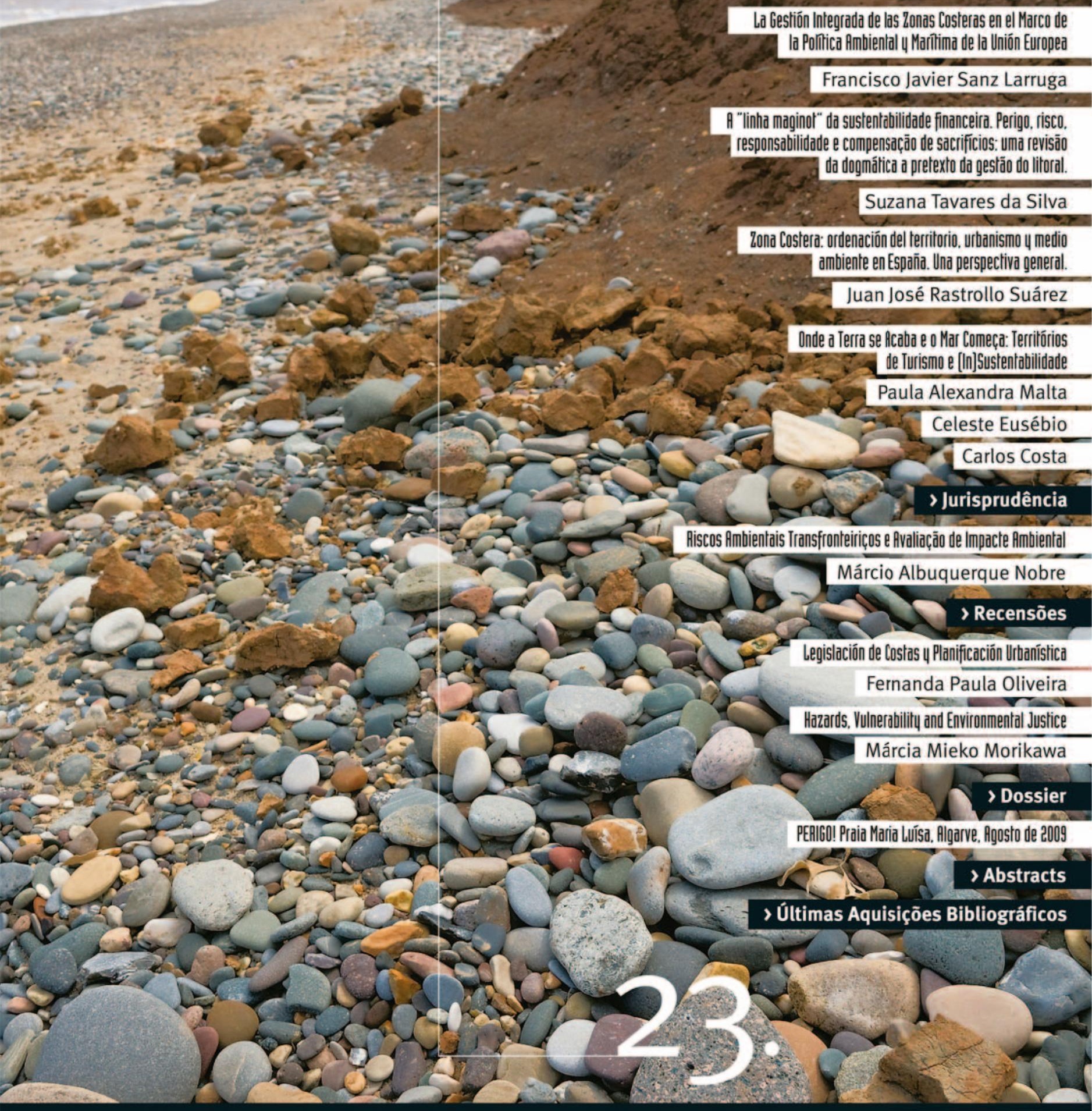

Revista do Centro de Estudos de Direito do Ordenamento, do Urbanismo e do Ambiente Urbanism, Territorial Order and Environment Studies Center Law Review 


\title{
Riscos Ambientais Transfronteiriços e Avaliação de Impacte Ambiental
}

International Court of Justice

\author{
YEAR 2010 \\ 2010 \\ 20 April \\ General List \\ No. 135 \\ 20 April 2010

\section{(ARGENTINA v. URUGUAY) *} \\ CASE CONCERNING PULP MILLS ON THE RIVER URUGUAY
}

(...)

\section{(a) Environmental Impact Assessment}

203. The Court will now turn to the relationship between the need for an environmental impact assessment, where the planned activity is liable to cause harm to a shared resource and transboundary harm, and the obligations of the Parties under Article 41 (a) and (b) of the 1975 Statute. The Parties agree on the necessity of conducting an environmental impact assessment. Argentina maintains that the obligations under the 1975 Statute viewed together impose an obligation to conduct an environmental impact assessment prior to authorizing Botnia to construct the plant. Uruguay also accepts that it is under such an obligation. The Parties disagree, however, with regard to the scope and content of the environmental impact assessment that Uruguay should have carried out with respect to the Orion (Botnia) mill project. Argentina maintains in the first place that Uruguay failed to ensure that "full environmental assessments [had been] produced, prior to its decision to authorize the construction ...."; and in the second place that "Uruguay's decisions [were] . . . based on unsatisfactory environmental assessments", in particular because Uruguay failed to take account of all potential impacts from the mill, even though international law and practice require it, and refers in this context to the 1991 Convention on Environmental Impact Assessment in a Transboundary Context of the United Nations Economic Commission for Europe (hereinafter the "Espoo Convention") (UNTS, Vol. 1989, p. 309), and the 1987 Goals and Principles of Environmental Impact Assessment of the United Nations Environment Programme (hereinafter the "UNEP Goals and Principles") (UNEP/WG.152/4 Annex (1987), document adopted by UNEP Governing Council at its 14th Session (Dec. 14/25 (1987)). Uruguay accepts that, in accordance with international practice, an environmental impact assessment of the Orion (Botnia) mill was necessary, but argues that international law does not impose any conditions upon the content of such an assessment, the preparation of which being a national, not international, procedure, at least where the

\footnotetext{
“ Considerando que a extensão do acórdão (80 págs. de texto mais 137 págs. de opiniões dissidentes, opiniões separadas e declarações) impede a sua reprodução integral, optámos por transcrever apenas o excerto em que se aborda a questão da obrigação de proceder à avaliação de impacte ambiental (parágrafos 203-219) e a Parte V que permite compreender os aspectos essenciais da controvérsia subjacente ao caso (parágrafos 267-282). A versão integral pode ser consultada em: http://www.icj-cij.org/.
} 


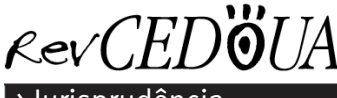

project in question is not one common to several States. According to Uruguay, the only requirements international law imposes on it are that there must be assessments of the project's potential harmful transboundary effects on people, property and the environment of other States, as required by State practice and the International Law Commission 2001 draft Articles on Prevention of Transboundary Harm from Hazardous Activities, without there being any need to assess remote or purely speculative risks.

204. It is the opinion of the Court that in order for the Parties properly to comply with their obligations under Article 41 (a) and (b) of the 1975 Statute, they must, for the purposes of protecting and preserving the aquatic environment with respect to activities which may be liable to cause transboundary harm, carry out an environmental impact assessment. As the Court has observed in the case concerning the Dispute Regarding Navigational and Related Rights,

"there are situations in which the parties' intent upon conclusion of the treaty was, or may be presumed to have been, to give the terms used - or some of them - a meaning or content capable of evolving, not one fixed once and for all, so as to make allowance for, among other things, developments in international law" (Dispute Regarding Navigational and Related Rights (Costa Rica v. Nicaragua), Judgment of 13 July 2009, para. 64).

In this sense, the obligation to protect and preserve, under Article 41 (a) of the Statute, has to be interpreted in accordance with a practice, which in recent years has gained so much acceptance among States that it may now be considered a requirement under general international law to undertake an environmental impact assessment where there is a risk that the proposed industrial activity may have a significant adverse impact in a transboundary context, in particular, on a shared resource. Moreover, due diligence, and the duty of vigilance and prevention which it implies, would not be considered to have been exercised, if a party planning works liable to affect the régime of the river or the quality of its waters did not undertake an environmental impact assessment on the potential effects of such works.

205. The Court observes that neither the 1975 Statute nor general international law specify the scope and content of an environmental impact assessment. It points out moreover that Argentina and Uruguay are not parties to the Espoo Convention. Finally, the Court notes that the other instrument to which Argentina refers in support of its arguments, namely, the UNEP Goals and Principles, is not binding on the Parties, but, as guidelines issued by an international technical body, has to be taken into account by each Party in accordance with Article 41 (a) in adopting measures within its domestic regulatory framework. Moreover, this instrument provides only that the "environmental effects in an EIA should be assessed with a degree of detail commensurate with their likely environmental significance" (Principle 5) without giving any indication of minimum core components of the assessment. Consequently, it is the view of the Court that it is for each State to determine in its domestic legislation or in the authorization process for the project, the specific content of the environmental impact assessment required in each case, having regard to the nature and magnitude of the proposed development and its likely adverse impact on the environment as well as to the need to exercise due diligence in conducting such an assessment. The Court also considers that an environmental impact assessment must be conducted prior to the implementation of a project. Moreover, once operations have started and, where necessary, throughout the life of the project, continuous monitoring of its effects on the environment shall be undertaken.

206. The Court has already considered the role of the environmental impact assessment in the context of the procedural obligations of the Parties under the 1975 Statute (paragraphs 119 and 120). It will now deal with the specific points in dispute with regard to the role of this type of assessment in the fulfilment of the substantive obligations of the Parties, that is to say, first, whether such an assessment should have, as a matter of method, necessarily considered possible alternative sites, taking into account the receiving capacity of the river in the area where the plant was to be built and, secondly, whether the populations likely to be affected, in this case both the Uruguayan and Argentine riparian populations, should have, or have in fact, been consulted in the context of the environmental impact assessment. 


\section{(i) The siting of the Orion (Botnia) mill at Fray Bentos}

207. According to Argentina, one reason why Uruguay's environmental impact assessment is inadequate is that it contains no analysis of alternatives for the choice of the mill site, whereas the study of alternative sites is required under international law (UNEP Goals and Principles, Espoo Convention, IFC Operational Policy 4.01). Argentina contends that the chosen site is particularly sensitive from an ecological point of view and unconducive to the dispersion of pollutants "[b]ecause of the nature of the waters which will receive the pollution, the propensity of the site to sedimentation and eutrophication, the phenomenon of reverse flow and the proximity of the largest settlement on the River Uruguay".

208. Uruguay counters that the Fray Bentos site was initially chosen because of the particularly large volume of water in the river at that location, which would serve to promote effluent dilution. Uruguay adds that the site is moreover easily accessible for river navigation, which facilitates delivery of raw materials, and local manpower is available there. Uruguay considers that, if there is an obligation to consider alternative sites, the instruments invoked for that purpose by Argentina do not require alternative locations to be considered as part of an environmental impact assessment unless it is necessary in the circumstances to do so. Finally, Uruguay affirms that in any case it did so and that the suitability of the Orion (Botnia) site was comprehensively assessed.

209. The Court will now consider, first, whether Uruguay failed to exercise due diligence in conducting the environmental impact assessment, particularly with respect to the choice of the location of the plant and, secondly, whether the particular location chosen for the siting of the plant, in this case Fray Bentos, was unsuitable for the construction of a plant discharging industrial effluent of this nature and on this scale, or could have a harmful impact on the river.

210. Regarding the first point, the Court has already indicated that the Espoo Convention is not applicable to the present case (see paragraph 205 above); while with respect to the UNEP Goals and Principles to which Argentina has referred, whose legal character has been described in paragraph 205 above, the Court recalls that Principle 4 (c) simply provides that an environmental impact assessment should include, at a minimum, "[a] description of practical alternatives, as appropriate". It is also to be recalled that Uruguay has repeatedly indicated that the suitability of the Fray Bentos location was comprehensively assessed and that other possible sites were considered. The Court further notes that the IFC's Final Cumulative Impact Study of September 2006 (hereinafter "CIS") shows that in 2003 Botnia evaluated four locations in total at La Paloma, at Paso de los Toros, at Nueva Palmira, and at Fray Bentos, before choosing Fray Bentos. The evaluations concluded that the limited amount of fresh water in La Paloma and its importance as a habitat for birds rendered it unsuitable, while for Nueva Palmira its consideration was discouraged by its proximity to residential, recreational, and culturally important areas, and with respect to Paso de los Toros insufficient flow of water during the dry season and potential conflict with competing water uses, as well as a lack of infrastructure, led to its exclusion. Consequently, the Court is not convinced by Argentina's argument that an assessment of possible sites was not carried out prior to the determination of the final site.

211. Regarding the second point, the Court cannot fail to note that any decision on the actual location of such a plant along the River Uruguay should take into account the capacity of the waters of the river to receive, dilute and disperse discharges of effluent from a plant of this nature and scale.

212. The Court notes, with regard to the receiving capacity of the river at the location of the mill, that the Parties disagree on the geomorphological and hydrodynamic characteristics of the river in the relevant area, particularly as they relate to river flow, and how the flow of the river, including its direction and its velocity, in turn determines the dispersal and dilution of pollutants. The differing views put forward by the Parties with regard to the river flow may be due to the different modelling systems which each has employed to analyse the hydrodynamic features of the River Uruguay at the Fray Bentos location. Argentina implemented a three-dimensional modelling that measured speed and direction at ten different depths of the river and used a sonar - an Acoustic 


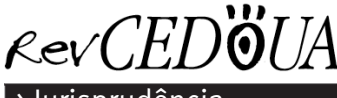

Doppler Current Profiler (hereafter "ADCP”) - to record water flow velocities for a range of depths for about a year. The three-dimensional system generated a large number of data later introduced in a numerical hydrodynamic model. On the other hand, Botnia based its environmental impact assessment on a bi-dimensional modelling - the RMA2. The EcoMetrix CIS implemented both three-dimensional and bi-dimensional models. However, it is not mentioned whether an ADCP sonar was used at different depths.

213. The Court sees no need to go into a detailed examination of the scientific and technical validity of the different kinds of modelling, calibration and validation undertaken by the Parties to characterize the rate and direction of flow of the waters of the river in the relevant area. The Court notes however that both Parties agree that reverse flows occur frequently and that phenomena of low flow and stagnation may be observed in the concerned area, but that they disagree on the implications of this for the discharges from the Orion (Botnia) mill into this area of the river.

214. The Court considers that in establishing its water quality standards in accordance with Articles 36 and 56 of the 1975 Statute, CARU must have taken into account the receiving capacity and sensitivity of the waters of the river, including in the areas of the river adjacent to Fray Bentos. Consequently, in so far as it is not established that the discharges of effluent of the Orion (Botnia) mill have exceeded the limits set by those standards, in terms of the level of concentrations, the Court finds itself unable to conclude that Uruguay has violated its obligations under the 1975 Statute. Moreover, neither of the Parties has argued before the Court that the water quality standards established by CARU have not adequately taken into consideration the geomorphological and hydrological characteristics of the river and the capacity of its waters to disperse and dilute different types of discharges. The Court is of the opinion that, should such inadequacy be detected, particularly with respect to certain areas of the river such as at Fray Bentos, the Parties should initiate a review of the water quality standards set by CARU and ensure that such standards clearly reflect the characteristics of the river and are capable of protecting its waters and its ecosystem.

\section{(ii) Consultation of the affected populations}

215. The Parties disagree on the extent to which the populations likely to be affected by the construction of the Orion (Botnia) mill, particularly on the Argentine side of the river, were consulted in the course of the environmental impact assessment. While both Parties agree that consultation of the affected populations should form part of an environmental impact assessment, Argentina asserts that international law imposes specific obligations on States in this regard. In support of this argument, Argentina points to Articles 2.6 and 3.8 of the Espoo Convention, Article 13 of the 2001 International Law Commission draft Articles on Prevention of Transboundary Harm from Hazardous Activities, and Principles 7 and 8 of the UNEP Goals and Principles. Uruguay considers that the provisions invoked by Argentina cannot serve as a legal basis for an obligation to consult the affected populations and adds that in any event the affected populations had indeed been consulted.

216. The Court is of the view that no legal obligation to consult the affected populations arises for the Parties from the instruments invoked by Argentina.

217. Regarding the facts, the Court notes that both before and after the granting of the initial environmental authorization, Uruguay did undertake activities aimed at consulting the affected populations, both on the Argentine and the Uruguayan sides of the river. These activities included meetings on 2 December 2003 in Río Negro, and on 26 May 2004 in Fray Bentos, with participation of Argentine non-governmental organizations. In addition, on 21 December 2004, a public hearing was convened in Fray Bentos which, according to Uruguay, addressed among other subjects, the

"handling of chemical products in the plant and in the port; the appearance of acid rain, dioxins, furans and other polychlorates of high toxicity that could affect the environment; compliance with the Stockholm Convention; atmospheric emissions of the plant; electromagnetic and electrostatic emissions; [and] liquid discharges into the river". 
Inhabitants of Fray Bentos and nearby regions of Uruguay and Argentina participated in the meeting and submitted 138 documents containing questions or concerns.

218. Further, the Court notes that between June and November 2005 more than 80 interviews were conducted by the Consensus Building Institute, a non-profit organization specializing in facilitated dialogues, mediation, and negotiation, contracted by the IFC. Such interviews were conducted inter alia in Fray Bentos, Gualeguaychú, Montevideo, and Buenos Aires, with interviewees including civil society groups, non-governmental organizations, business associations, public officials, tourism operators, local business owners, fishermen, farmers and plantation owners on both sides of the river. In December 2005, the draft CIS and the report prepared by the Consensus Building Institute were released, and the IFC opened a period of consultation to receive additional feedback from stakeholders in Argentina and Uruguay.

219. In the light of the above, the Court finds that consultation by Uruguay of the affected populations did indeed take place.

\section{(...)}

\section{The claims made by the parties in their final submissions}

267. Having concluded that Uruguay breached its procedural obligations under the 1975 Statute (see paragraphs 111, 122, 131, 149, 157 and 158 above), it is for the Court to draw the conclusions following from these internationally wrongful acts giving rise to Uruguay's international responsibility and to determine what that responsibility entails.

268. Argentina first requests the Court to find that Uruguay has violated the procedural obligations incumbent on it under the 1975 Statute and has thereby engaged its international responsibility. Argentina further requests the Court to order that Uruguay immediately cease these internationally wrongful acts.

269. The Court considers that its finding of wrongful conduct by Uruguay in respect of its procedural obligations per se constitutes a measure of satisfaction for Argentina. As Uruguay's breaches of the procedural obligations occurred in the past and have come to an end, there is no cause to order their cessation.

270. Argentina nevertheless argues that a finding of wrongfulness would be insufficient as reparation, even if the Court were to find that Uruguay has not breached any substantive obligation under the 1975 Statute but only some of its procedural obligations. Argentina maintains that the procedural obligations and substantive obligations laid down in the 1975 Statute are closely related and cannot be severed from one another for purposes of reparation, since undesirable effects of breaches of the former persist even after the breaches have ceased. Accordingly, Argentina contends that Uruguay is under an obligation to "re-establish on the ground and in legal terms the situation that existed before [the] internationally wrongful acts were committed". To this end, the Orion (Botnia) mill should be dismantled. According to Argentina, restitutio in integrum is the primary form of reparation for internationally wrongful acts. Relying on Article 35 of the International Law Commission's Articles on the Responsibility of States for Internationally Wrongful Acts, Argentina maintains that restitution takes precedence over all other forms of reparation except where it is "materially impossible" or involves "a burden out of all proportion to the benefit deriving from restitution instead of compensation". It asserts that dismantling the mill is not materially impossible and would not create for the Respondent State a burden out of all proportion, since the Respondent has

"maintained that construction of the mills would not amount to a fait accompli liable to prejudice Argentina's rights and that it was for Uruguay alone to decide whether to proceed with construction and thereby assume the risk of having to dismantle the mills in the event of an adverse decision by the Court",

as the Court noted in its Order on Argentina's request for the indication of provisional measures in this case (Order of 13 July 2006, I.C.J. Reports 2006, p. 125, para. 47). Argentina adds that whether or 
not restitution is disproportionate must be determined at the latest as of the filing of the Application instituting proceedings, since as from that time Uruguay, knowing of Argentina's request to have the work halted and the status quo ante re-established, could not have been unaware of the risk it ran in proceeding with construction of the disputed mill. Lastly, Argentina considers Articles 42 and 43 of the 1975 Statute to be inapplicable in the present case, since they establish a régime of responsibility in the absence of any wrongful act.

271. Taking the view that the procedural obligations are distinct from the substantive obligations laid down in the 1975 Statute, and that account must be taken of the purport of the rule breached in determining the form to be taken by the obligation of reparation deriving from its violation, Uruguay maintains that restitution would not be an appropriate form of reparation if Uruguay is found responsible only for breaches of procedural obligations. Uruguay argues that the dismantling of the Orion (Botnia) mill would at any rate involve a "striking disproportion between the gravity of the consequences of the wrongful act of which it is accused and those of the remedy claimed", and that whether or not a disproportionate burden would result from restitution must be determined as of when the Court rules, not, as Argentina claims, as of the date it was seised. Uruguay adds that the 1975 Statute constitutes a lex specialis in relation to the law of international responsibility, as Articles 42 and 43 establish compensation, not restitution, as the appropriate form of reparation for pollution of the river in contravention of the 1975 Statute.

272. The Court, not having before it a claim for reparation based on a régime of responsibility in the absence of any wrongful act, deems it unnecessary to determine whether Articles 42 and 43 of the 1975 Statute establish such a régime. But it cannot be inferred from these articles, which specifically concern instances of pollution, that their purpose or effect is to preclude all forms of reparation other than compensation for breaches of procedural obligations under the 1975 Statute.

273. The Court recalls that customary international law provides for restitution as one form of reparation for injury, restitution being the re-establishment of the situation which existed before occurrence of the wrongful act. The Court further recalls that, where restitution is materially impossible or involves a burden out of all proportion to the benefit deriving from it, reparation takes the form of compensation or satisfaction, or even both (see Gabcíkovo-Nagymaros Project (Hungary/Slovakia), Judgment, I.C.J. Reports 1997, p. 81, para. 152; Legal Consequences of the Construction of a Wall in the Occupied Palestinian Territory, Advisory Opinion, I.C.J. Reports 2004 (I), p. 198, paras. 152-153; Application of the Convention on the Prevention and Punishment of the Crime of Genocide (Bosnia and Herzegovina v. Serbia and Montenegro), Judgment, I.C.J. Reports 2007, p. 233, para. 460; see also Articles 34 to 37 of the International Law Commission Articles on the Responsibility of States for Internationally Wrongful Acts).

274. Like other forms of reparation, restitution must be appropriate to the injury suffered, taking into account the nature of the wrongful act having caused it. As the Court has made clear,

\begin{abstract}
“[w] hat constitutes 'reparation in an adequate form' clearly varies depending upon the concrete circumstances surrounding each case and the precise nature and scope of the injury, since the question has to be examined from the viewpoint of what is the 'reparation in an adequate form' that corresponds to the injury" (Avena and Other Mexican Nationals (Mexico v. United States of America), Judgment, I.C.J. Reports 2004 (I), p. 59, para. 119).
\end{abstract}

275. As the Court has pointed out (see paragraphs 154 to 157 above), the procedural obligations under the 1975 Statute did not entail any ensuing prohibition on Uruguay's building of the Orion (Botnia) mill, failing consent by Argentina, after the expiration of the period for negotiation. The Court has however observed that construction of that mill began before negotiations had come to an end, in breach of the procedural obligations laid down in the 1975 Statute. Further, as the Court has found, on the evidence submitted to it, the operation of the Orion (Botnia) mill has not resulted in the breach of substantive obligations laid down in the 1975 Statute (paragraphs 180, 189 and 265 above). As Uruguay was not barred from proceeding with the construction and operation of the Orion (Botnia) mill after the expiration of the period for negotiation and as it breached no substantive obligation under the 1975 Statute, ordering the dismantling of the mill would not, in the view of the Court, constitute an appropriate remedy for the breach of procedural obligations. 
276. As Uruguay has not breached substantive obligations arising under the 1975 Statute, the Court is likewise unable, for the same reasons, to uphold Argentina's claim in respect of compensation for alleged injuries suffered in various economic sectors, specifically tourism and agriculture.

277. Argentina further requests the Court to adjudge and declare that Uruguay must "provide adequate guarantees that it will refrain in future from preventing the Statute of the River Uruguay of 1975 from being applied, in particular the consultation procedure established by Chapter II of that Treaty".

278. The Court fails to see any special circumstances in the present case requiring the ordering of a measure such as that sought by Argentina. As the Court has recently observed:

"[W]hile the Court may order, as it has done in the past, a State responsible for internationally wrongful conduct to provide the injured State with assurances and guarantees of non-repetition, it will only do so if the circumstances so warrant, which it is for the Court to assess.

As a general rule, there is no reason to suppose that a State whose act or conduct has been declared wrongful by the Court will repeat that act or conduct in the future, since its good faith must be presumed (see Factory at Chorzów, Merits, Judgment No. 13, 1928, P.C.I.J., Series A, No. 17, p. 63; Nuclear Tests (Australia v. France), Judgment, I.C.J. Reports 1974, p. 272, para. 60; Nuclear Tests (New Zealand v. France), Judgment, I.C.J. Reports 1974, p. 477, para. 63; and Military and Paramilitary Activities in and against Nicaragua (Nicaragua v. United States of America), Jurisdiction and Admissibility, Judgment, I.C.J. Reports 1984, p. 437, para. 101). There is thus no reason, except in special circumstances ... to order [the provision of assurances and guarantees of non-repetition]." (Dispute regarding Navigational and Related Rights (Costa Rica v. Nicaragua), Judgment of 13 July 2009 , para. 150 .)

279. Uruguay, for its part, requests the Court to confirm its right "to continue operating the Botnia plant in conformity with the provisions of the 1975 Statute". Argentina contends that this claim should be rejected, in particular because it is a counter-claim first put forward in Uruguay's Rejoinder and, as such, is inadmissible by virtue of Article 80 of the Rules of Court.

280. There is no need for the Court to decide the admissibility of this claim; it is sufficient to observe that Uruguay's claim is without any practical significance, since Argentina's claims in relation to breaches by Uruguay of its substantive obligations and to the dismantling of the Orion (Botnia) mill have been rejected.

281. Lastly, the Court points out that the 1975 Statute places the Parties under a duty to co-operate with each other, on the terms therein set out, to ensure the achievement of its object and purpose. This obligation to co-operate encompasses ongoing monitoring of an industrial facility, such as the Orion (Botnia) mill. In that regard the Court notes that the Parties have a long-standing and effective tradition of co-operation and co-ordination through CARU. By acting jointly through CARU, the Parties have established a real community of interests and rights in the management of the River Uruguay and in the protection of its environment. They have also co-ordinated their actions through the joint mechanism of CARU, in conformity with the provisions of the 1975 Statute, and found appropriate solutions to their differences within its framework without feeling the need to resort to the judicial settlement of disputes provided for in Article 60 of the Statute until the present case was brought before the Court.

282. For these reasons,

THE COURT,

(1) By thirteen votes to one,

Finds that the Eastern Republic of Uruguay has breached its procedural obligations under Articles 7 to 12 of the 1975 Statute of the River Uruguay and that the declaration by the Court of this breach constitutes appropriate satisfaction; 


\section{$\operatorname{RerCEDőUA~}$ \\ > Jurisprudência}

IN FAVOUR: Vice-President Tomka, Acting President; Judges Koroma, Al-Khasawneh, Simma, Abraham, Keith, Sepúlveda-Amor, Bennouna, Skotnikov, Cançado Trindade, Yusuf, Greenwood; Judge ad hoc Vinuesa;

AGAINST: Judge ad hoc Torres Bernárdez;

(2) By eleven votes to three,

Finds that the Eastern Republic of Uruguay has not breached its substantive obligations under Articles 35, 36 and 41 of the 1975 Statute of the River Uruguay;

IN FAVOUR: Vice-President Tomka, Acting President; Judges Koroma, Abraham, Keith, Sepúlveda-Amor, Bennouna, Skotnikov, Cançado Trindade, Yusuf, Greenwood; Judge ad hoc Torres Bernárdez;

AGAINST: Judges Al-Khasawneh, Simma; Judge ad hoc Vinuesa;

(3) Unanimously,

Rejects all other submissions by the Parties.

Done in French and in English, the French text being authoritative, at the Peace Palace, The Hague, this twentieth day of April, two thousand and ten, in three copies, one of which will be placed in the archives of the Court and the others transmitted to the Government of the Argentine Republic and the Government of the Eastern Republic of Uruguay, respectively.

(Signed) Peter TOMKA, Vice-President.

(Signed) Philippe OUVREUR, Registrar.

Judges AL-KHASAWNEH and SIMMA append a joint dissenting opinion to the Judgment of the Court; Judge KEITH appends a separate opinion to the Judgment of the Court; Judge SKOTNIKOV appends a declaration to the Judgment of the Court; Judge CANÇADO TRINDADE appends a separate opinion to the Judgment of the Court; Judge YUSUF appends a declaration to the Judgment of the Court; Judge GREENWOOD appends a separate opinion to the Judgment of the Court; Judge ad hoc TORRES BERNÁRDEZ appends a separate opinion to the Judgment of the Court; Judge ad hoc VINUESA appends a dissenting opinion to the Judgment of the Court.

(Initialled) P. T. (Initialled) Ph. C.

\section{Comentário}

\section{Riscos ambientais transfronteiriços}

Os riscos ambientais apresentam hoje, em virtude da actividade humana, desafios que não podem ser superados pela acção isolada de um Estado. Por um lado, não há fronteira que detenha os riscos ambientais. Pense-se, por exemplo, no caso ocorrido na cidade de Bâle (Suiça), em que o incêndio ocorrido numa indústria de produtos químicos emitiu fumos tóxicos para a República Federal Alemã e causou o derrame de produtos químicos tóxicos 
no Rio Reno, levando não só à destruição dos ecossistemas ribeirinhos como também à perturbação do abastecimento de água dos países situados a jusante (França, Alemanha, Holanda) ${ }^{1}$. Por outro lado, os Estados têm cada vez mais dificuldade em enfrentar os riscos ambientais sem o auxílio, material ou financeiro, de outros Estados. Neste sentido, atente-se para a recente maré negra resultante da explosão ocorrida em de Abril de 2010 numa plataforma petrolífera pertencente à BP (British Petroleum) situada no Golfo do México. $\mathrm{Na}$ nossa opinião, este caso demonstra que mesmo uma superpotência como os EUA pode ver-se perante a carência da tecnologia necessária para enfrentar um dos piores desastres ambientais da sua história.

A prevenção e gestão dos riscos ambientais exige portanto a acção coordenada de vários Estados. Esta coordenação pode consubstanciar-se no estabelecimento de deveres de informação e comunicação, como por exemplo: (i) informar os outros Estados sobre os projectos que se pretendem concretizar; ou (ii) comunicar a ocorrência de acidentes industriais ${ }^{2}$. Podem também ser previstas obrigações de negociação (por exemplo: obrigação de obter um consenso sobre os aproveitamentos a realizar nas margens de um rio), obrigações de auxílio mútuo, ou ainda obrigações de contribuir para fundos susceptíveis de serem mobilizados em caso de concretização dos riscos ambientais. Finalmente, e sem a pretensão de fornecer um quadro exaustivo, a coordenação da acção dos Estados pode traduzir-se na adopção de planos comuns de prevenção de riscos ${ }^{3}$.

Todavia, existem situações em que os Estados não actuam em coordenação com outros Estados para salvaguardar determinados bens ambientais. Nesses casos, podem surgir controvérsias a propósito de decisões unilaterais de um Estado que comprometem um bem ambiental partilhado ou pertencente a outro Estado, sem que este último tenha participado na decisão. É exactamente neste contexto que se insere o presente acórdão em que o Tribunal Internacional de Justiça (TIJ) é chamado a pronunciar-se sobre a aplicação de um Estatuto relativo à gestão de um recurso natural partilhado pelo Uruguai e pela Argentina: o Rio Uruguai.

\section{Cursos de água internacionais}

Uma vez que a água é um recurso indispensável não só para vida humana mas também para a maioria das actividades desenvolvidas pelo Homem, não é surpreendente o surgimento de controvérsias interestaduais quanto ao aproveitamento deste mesmo recurso natural ${ }^{4}$.

Na verdade, não é a primeira vez que o TIJ lida com casos que envolvem a gestão de cursos de água partilhados por vários Estados. No célebre caso Gabcíkovo Nagymaros, que opôs a Hungria à Eslováquia, o TIJ foi chamado a pronunciar-se sobre a violação de um acordo relativo a um projecto hidroeléctrico celebrado entre dois Estados. Neste caso, a Hungria

\footnotetext{
${ }^{1}$ A título de curiosidade, informamos que a necessidade de gerir internacionalmente as águas do Reno levou à criação da primeira organização internacional: a Comissão Central para a Navegação do Reno.

${ }^{2}$ Ver a este propósito o art. $24 .{ }^{\circ}$ do Decreto-Lei n.. 147/2008, de 29 de Julho, que estabelece o regime jurídico da responsabilidade por danos ambientais, que prevê as medidas a adoptar pelas autoridades competentes em caso de ocorrência de dano ambiental transfronteiriço ou ameaça iminente do mesmo.

${ }^{3}$ A Directiva 2007/60/CE, de 23 de Outubro, relativa à avaliação e gestão dos riscos de inundações, prevê no art. 8.ำ n. .2 que nas regiões hidrográficas internacionais os Estados-Membros devem assegurar a coordenação de forma a elaborarem um plano único de gestão dos riscos de inundações ou um conjunto de planos de gestão dos riscos de inundações coordenados a nível da região hidrográfica internacional.

4 Para uma exposição das principais controvérsias relativas ao uso de cursos de água internacionais, ver STEPHEN C. MCCAFFREY, The Law of International Watercourses. Non-Navigational Uses, Oxford, 2001, p. 179 e segs.
} 
decidiu abandonar unilateralmente a construção do projecto, invocando como fundamento a susceptibilidade de o projecto afectar irreversivelmente bens ambientais que constituíam um interesse essencial do Estado húngaro.

Contudo, o caso Gabcíkovo Nagymaros distingue-se do caso que pretendemos analisar. No caso Gabcíkovo Nagymaros invoca-se a protecção de bens ambientais de interesse essencial para excluir a ilicitude do incumprimento de obrigações assumidas pela Hungria em relação à Eslováquia (que sucedeu à Checoslováquia) - a protecção ambiental é aqui invocada como causa de exclusão da ilicitude. Inversamente, no caso relativo às fábricas de celulose no Rio Uruguai, a Argentina suscita a intervenção do TIJ na medida em que considera que 0 comportamento do Uruguai ameaça o equilíbrio ecológico do Rio Uruguai.

\section{Coordenação interestadual e protecção do equilíbrio ecológico do Rio Uruguai}

No dia 26 de Fevereiro de 1975 o Governo da República da Argentina e o Governo da República Oriental do Uruguai assinaram o Estatuto do Rio Uruguai (daqui em diante Estatuto). O principal objectivo do Estatuto foi a criação dos mecanismos comuns necessários para a racionalização e optimização do aproveitamento do Rio Uruguai (art. 1.ำ do Estatuto). 0 Estatuto assume-se, portanto, como um instrumento jurídico que visa promover a cooperação do Uruguai e da Argentina na gestão de um curso de água que estabelece uma fronteira entre os dois Estados.

No sentido de coordenar o aproveitamento do Rio Uruguai, foi criada a Comissão Administradora do Rio Uruguai (CARU). Trata-se de uma entidade que goza de personalidade jurídica (art. 50. do Estatuto) e por intermédio da qual se coordenam, designadamente, as medidas a adoptar com vista a evitar alterações do equilíbrio ecológico e a controlar pragas e outros factores nocivos no Rio Uruguai e nas suas áreas de influência (art. 36.ํ do Estatuto).

Além disso, o Estatuto consagra ainda um procedimento que deve ser seguido sempre que uma das Partes (Argentina ou Uruguai) projecte a construção de novos canais, a modificação ou alteração significativa dos já existentes ou a realização de quaisquer outras obras com importância suficiente para afectar a navegação, o regime do rio ou a qualidade das suas águas. Num primeiro momento, impende sobre a Parte que pretende realizar a obra uma obrigação de comunicar o seu projecto à CARU que, num prazo de 30 dias, deverá determinar sumariamente se o mesmo é susceptível de causar um prejuízo significativo à outra Parte (art. 7. ${ }^{\circ}$ do Estatuto). No caso de as obras projectadas serem susceptíveis de causar um prejuízo significativo ou de não se chegar a nenhuma decisão a esse respeito, a Parte interessada deverá notificar a outra Parte por intermédio da CARU (art. 7..$^{0}$ do Estatuto) ${ }^{5}$. A Parte notificada terá então um prazo de 180 dias para se pronunciar sobre o projecto. Se não levantar objecções ou não contestar o projecto dentro do prazo previsto, então a Parte promotora do projecto poderá autorizar a realização da obra projectada (art. 9. 0 do Estatuto). A Parte notificada preserva todavia a faculdade de inspeccionar a execução das referidas obras (art. 10.은 do Estatuto). Se, pelo contrário, a Parte notificada tiver alguma objecção, deverá comunicar à outra Parte as razões que subjazem a essa mesma objecção e apresentar sugestões de alteração do projecto ou programa em causa. Finalmente, na ausência de acordo, as Partes poderão submeter ao TIJ a resolução da controvérsia (arts. 12.ำ e 60. do Estatuto).

\footnotetext{
${ }^{5} 0$ Estatuto clarifica que a notificação deverá incluir os aspectos essenciais que permitam à Parte notificada avaliar os efeitos prováveis que a obra terá ao nível da navegação, do regime do Rio e da qualidade das suas águas.
} 
Como pode depreender-se do exposto, o regime jurídico previsto no Estatuto tem em alto apreço o valor da protecção ambiental. Aliás, este Estatuto é bastante avançado para época. Se tivermos como ponto de referência a Convenção das Nações Unidas sobre o Direito relativo à Utilização dos Cursos de Água para Fins Diversos dos de Navegação de 1997, podemos perceber que o Estatuto antecede em mais de duas décadas tanto as obrigações de informação, notificação e negociação de medidas projectadas (arts. 11.ํe ss. da Convenção), como as obrigações de prevenir, reduzir e controlar a poluição dos cursos de água (arts. 20.ำ ss. da Convenção). E se compararmos o Estatuto com os instrumentos convencionais aprovados por Portugal e Espanha no domínio da gestão das bacias hidrográficas internacionais, poderemos comprovar que só com a Convenção sobre a Cooperação para a Proteç̧ão e o Aproveitamento Sustentável das Águas das Bacias Hidrográficas Luso-Espanholas, aprovada pela Resolução da Assembleia da República n. 66/99, de 25 de Junho, é que se começaram a prever obrigações relativas ao aproveitamento sustentável dos recursos hídricos e à prevenção, redução, eliminação e controlo da poluição ambiental ${ }^{6}$.

\section{Autorização unilateral de projectos de fábricas de celulose}

No ano de 2005, a República Oriental do Uruguai autorizou a implantação de duas fábricas de celulose próximo de uma localidade chamada Fray Bentos, situada na margem esquerda do Rio Uruguai'. Uma das fábricas, que acabaria por não ser concluída, pertencia à sociedade "Celulosas de M`Bopicuá S.A." (criada pela sociedade espanhola "Empresa Nacional de Celulosas de España"). A outra unidade fabril, denominada "Orion (Botnia)", pertencia às sociedades "Botnia S. A." e "Botnia Fray Bentos S.A." (criadas pela sociedade finlandesa "Oy Metsä-Botnia AB"), mas foi adquirida em Dezembro de 2009 pela sociedade “UPM-Kymmene Oyj”.

Todavia, como resulta do Estatuto acima analisado, o Uruguai e a Argentina não podem autorizar obras localizadas nas margens do Rio Uruguai sem cumprir um procedimento prévio que envolve a intervenção da CARU. A autorização destes empreendimentos na margem esquerda do Rio Uruguai não poderia ser realizada à margem das obrigações de informar, notificar e negociar. No entanto, foi exactamente isso que sucedeu: o Uruguai não informou a CARU dos seus projectos; o Uruguai não notificou a Argentina nos termos do Estatuto; e, consequentemente, o Uruguai obstou à possibilidade de realizar negociações com a Argentina.

Perante o comportamento do Uruguai, a única possibilidade que restou à Argentina para compelir o Uruguai ao cumprimento das suas obrigações foi a de recorrer ao TIJ nos termos dos arts. $12 . .^{\circ}$ e $60 . .9$ do Estatuto.

\section{Resolução judicial da controvérsia}

Em Maio de 2006, a Argentina intentou uma acção contra o Uruguai junto do TIJ. Invocou a violação das normas do Estatuto, e sublinhou que a autorização da construção, a construção e a eventual entrada em funcionamento das fábricas de celulose iria ter efeitos

\footnotetext{
${ }^{6}$ Cfr. J. J. GOMES CANOTILHO (org.), O Regime Jurídico Internacional dos Rios Transfronteiriços, Coimbra, 2006 p. 527 e ss.

${ }^{7}$ No ano de 2007, o Governo Uruguaio iniciou também contactos com uma sociedade portuguesa: a "Portucel Empresa de Produção de Pasta e Papel S.A.”. Este facto foi comunicado pelo grupo Portucel à CMVM: http://www. portucelsoporcel.com/pt/investors_relevant_facts/news.
} 
nocivos nas águas do Rio Uruguai e na sua zona de influência ${ }^{8}$. No sentido de prevenir os riscos inerentes ao funcionamento da fábrica, a Argentina requereu também a adopção de medidas conservatórias.

O TIJ não acedeu ao pedido de adopção de medidas conservatórias, permitindo desta forma que a "Orion (Botnia)" iniciasse a sua actividade. E no acórdão de 20 de Abril de 2010 acabou por considerar que o Uruguai apenas havia violado obrigações de natureza procedimental. Assim, admitiu que Uruguai não tinha cumprido as obrigações de informar, notificar e negociar. Em contrapartida, declarou que a Argentina não conseguiu provar cabalmente os efeitos nocivos para ambiente que havia invocado. 0 TIJ conclui portanto que o Uruguai cumpriu as obrigações materiais que sobre ele impendiam. 0 encerramento da fábrica de celulose - pedido pela Argentina depois da mesma ter entrado em funcionamento - estaria por isso fora de questão. A Argentina teria de se contentar com a mera declaração de violação das obrigações procedimentais.

O nosso objectivo no texto que se segue será o de apresentar uma breve reflexão crítica sobre alguns dos aspectos essenciais do acórdão ${ }^{9}$. Em primeiro lugar, abordaremos a questão de saber se existe ou não uma obrigação de não construção no Estatuto. Em seguida, tentaremos demonstrar que o TIJ não avaliou adequadamente os dados que foram apresentados pelas partes. Por fim, procederemos à análise dos contributos do presente acórdão para a resolução de futuras controvérsias no domínio dos riscos ambientais transfronteiriços.

\section{Obrigação de não construção: instrumento de coordenação e prevenção}

Como salientámos acima, o Estatuto teve como finalidade a criação dos mecanismos comuns necessários para a racionalização e optimização do aproveitamento do Rio Uruguai (art. 1.ํ do Estatuto). A coordenação das formas de aproveitamento do Rio Uruguai é um dos fins do Estatuto. Assim, são contrárias ao Estatuto todas as actuações unilaterais das Partes. E compreende-se que assim seja visto que, sendo o Rio Uruguai um curso de água partilhado pela Argentina e pelo Uruguai, os aproveitamentos realizados no território de cada uma das Partes podem ter consequências na esfera da outra.

Deste modo, a autorização da implantação de uma fábrica de celulose, cujo funcionamento implica a realização de descargas para as águas do Rio Uruguai, é um aproveitamento que não deveria ter sido determinado unilateralmente.

Todavia, não foi este o entendimento do TIJ. Na verdade, esta instância considerou que, após a realização do procedimento de informação, notificação e negociação, as Partes têm a liberdade de efectuar os aproveitamentos que projectaram, mesmo que não tenham conseguido chegar a acordo com a outra Parte. E acrescentou que a Parte que pretende realizar o aproveitamento nem sequer tem de esperar pela resolução definitiva da controvérsia pelo TIJ.

\footnotetext{
${ }^{8}$ A Argentina invocou também a violação de normas de acordos internacionais aplicáveis às Partes nos termos do art. 41.․ do Estatuto, mas o TIJ considerou que a sua jurisdição só lhe permitia conhecer das violações das obrigações previstas no Estatuto.

${ }_{9}$ Ao longo da nossa reflexão seguiremos de perto as críticas contidas nas opiniões dissidentes do Juiz ad hoc Vinuesa, e dos Juízes Al-Khasawneh e Simma.
} 
Na nossa opinião, esta interpretação realizada pelo TIJ faz com que o procedimento previsto no Estatuto não passe de uma mera formalidade. Conceder ao Uruguai o direito de implantar a fábrica de celulose sem o consentimento da Argentina é o mesmo que inutilizar, na prática, as obrigações de informar, notificar e negociar. Se a Parte que pretende realizar o projecto já sabe à partida que não necessita do consentimento da outra Parte para o concretizar, então o poder negocial desta última é igual a zero.

Para além disso, também não acompanhamos o entendimento do TIJ quando declara que o Uruguai tinha o direito de implantar a fábrica antes da resolução judicial da controvérsia. A possibilidade de recurso ao TIJ deve ser encarada como mais uma etapa no sentido de obter uma decisão definitiva e vinculativa para as duas Partes. Não concordamos por isso com o TIJ quando afirma, por um lado, que o Uruguai podia implantar a fábrica de celulose independentemente da obtenção de acordo com a Argentina e, por outro lado, que o Uruguai tinha apenas de suportar o risco de a decisão final do conflito acarretar o encerramento da fábrica e a responsabilização pelos danos provocados. Esta interpretação do TIJ não só contraria a garantia da coordenação internacional do aproveitamento do Rio Uruguai - uma das finalidades expressas do Estatuto - como também obsta à prevenção de riscos ambientais (art. 36. do Estatuto).

Com efeito, uma análise atenta do art. 36. - - "Las Partes coordinarán, por intermedio de la Comisión, las medidas adecuadas a fin de evitar la alteración del equilibrio ecológico y controlar plagas y otros factores nocivos en el Río y sus áreas de influencia" - permite concluir que o Estatuto visa a adopção de medidas preventivas que impeçam a produção de danos ambientais no Rio Uruguai. E tratando-se de um bem ambiental partilhado por dois Estados, torna-se óbvio que essa prevenção só será eficaz se existir coordenação entre as Partes. Se só uma das Partes estiver determinada na prevenção dos riscos ambientais, não é garantida a salvaguarda do equilíbrio ecológico. Só a convergência de vontades permitirá uma prevenção efectiva. Quando esta convergência não for conseguida através de negociações directas, deve recorrer-se ao TIJ para obter uma solução definitiva.

Em suma, o entendimento do TIJ desprezou completamente a prevenção de riscos ambientais. Ao declarar que o Uruguai tinha o direito de implantar a fábrica por sua conta e risco, antes da decisão final do caso, o TIJ demonstra que só perspectiva o caso na óptica de uma eventual responsabilização do Uruguai. Consideramos portanto que o TIJ não só procedeu a uma aplicação incorrecta do próprio Estatuto, como também perdeu uma oportunidade de efectuar uma aproximação preventiva aos riscos ambientais transfronteiriços - revelando assim alguma falta de sensibilidade quanto à necessidade de prevenir riscos que só são produzidos por uma das Partes mas podem concretizar-se na esfera de ambas.

\section{Entre a absolvição na dúvida e a dúvida na absolvição}

O TIJ declarou no acórdão de 20 de Abril de 2010 que só no caso de serem violadas obrigações materiais é que o Uruguai seria obrigado a encerrar a fábrica de celulose. Isto significa que, no caso concreto, a procedência da pretensão da Argentina estava dependente da prova de que as descargas da fábrica de celulose eram susceptíveis de provocar danos.

A avaliação dos dados relativos à prova da violação das obrigações materiais foi um dos aspectos mais controvertidos no seio do $\mathrm{TIJ}^{10}$. Contudo, foi exactamente nesta avaliação que o TIJ se fundou para declarar que o Uruguai não havia violado as suas obrigações materiais.

\footnotetext{
${ }^{10}$ Ver as opiniões dissidentes do Juiz ad hoc Vinuesa, e dos Juízes Al-Khasawneh e Simma.
} 
Desta forma, é habitual encontrar ao longo do acórdão expressões como: "não demonstrou de forma convincente", "o Tribunal não está em posição para concluir", "não existe prova suficiente", "não ficou estabelecido no entendimento do tribunal", "não existem provas suficientes para concluir", "não ficou claramente estabelecido o nexo de causalidade". Mais do que a falta de prova, estas expressões reflectem, no nosso entender, a dificuldade do tribunal em extrair conclusões a partir dos dados que the foram apresentados por ambas as Partes. Assim, e em função das incertezas existentes, o TIJ não se deveria ter limitado a ouvir os peritos apresentados pelas Partes nos termos do art. $43 .^{\circ}$ do ETIJ, desde logo por causa da relação de dependência subjacente ${ }^{11}$.

Na nossa opinião, a solução mais adequada seria o recurso à faculdade consagrada no art. 50. do ETIJ: "O Tribunal poderá, em qualquer momento, cometer a qualquer indivíduo, entidade, repartição, comissão ou outra organização à sua escolha a tarefa de proceder a um inquérito ou a uma peritagem" "12. Trata-se de uma hipótese que já foi utilizada pelo TIJ no Caso Canal do Corfu, que opôs o Reino Unido à Albânia, em 1949. 0 não recurso a esta hipótese obstou a uma avaliação séria dos dados apresentados. Ousamos mesmo afirmar que o TIJ procurou não se colocar numa situação em que fosse obrigado a proferir a condenação do Uruguai no encerramento da fábrica. Apresentamos de seguida três situações em que tentaremos comprovar esta afirmação.

A propósito dos níveis de concentração de AOX (componentes de halogéneo orgânicos absorvíveis) nas águas do Rio Uruguai, ficou estabelecido que no dia 9 de Janeiro de 2008 foi atingida uma concentração de $13 \mathrm{mg} / \mathrm{l}$, quando o limite máximo admitido era de $6 \mathrm{mg} / \mathrm{l}$. Perante este facto, o TIJ declarou o seguinte: "na ausência de elementos de prova que estabeleçam de forma convincente que não se trata de um episódio isolado mas de um problema mais duradouro, o Tribunal não está em condições de concluir que o Uruguai violou as disposições do Estatuto de $197{ }^{\text {"13 }}$. Não concordamos com a posição assumida pelo tribunal. Se é verdade que nada permitia concluir que se tratava de um problema duradouro, também não existiam dados que demonstrassem que estava perante uma situação excepcional. Para além disso, uma vez provada a violação dos limites de concentração permitidos, consideramos que o ónus de provar a excepcionalidade do facto deveria recair sobre o Uruguai.

Relativamente ao nível de concentração de fósforo nas águas do Rio Uruguai, julgamos pertinente a citação de um Relatório da DINAMA ("Dirección Nacional de Médio Ambiente"): "a fábrica verterá um total de 200 toneladas/ano de azoto e 20 toneladas/ano de fósforo, valores que equivalem aproximadamente aos produzidos por uma cidade de 65 mil habitantes desprovida de sistema de tratamento de águas residuais". Em seguida acrescenta-se: "seria desaconselhável autorizar a descarga de resíduos susceptíveis de aumentar o valor de qualquer parâmetro que já tenha atingido um nível crítico, mesmo quando este aumento seja considerado como insignificante pela empresa". E, por fim, conclui-se: "a descarga de resíduos proposta no projecto poderia ser aceite, sob condição de prever uma compensação nos casos em que seja ultrapassado o valor standard de qualquer um dos parâmetros críticos".

\footnotetext{
${ }^{11} \mathrm{O}$ acórdão alerta ainda para o facto de certos intervenientes no processo actuarem simultaneamente como consultores ou advogados das Partes e como peritos. 0 TIJ declarou que o mais adequado nestes casos seria o seguinte: aqueles que pretendessem fornecer provas técnicas ou científicas deveriam apresentar-se como testemunhas perito ("expert witnesses"), de modo a poderem ser questionados pela outra Parte e pelo tribunal.

${ }^{12}$ Sobre a oportunidade da aplicação do artigo 50. do Estatuto do Tribunal Internacional de Justiça (ETIJ), relativo ao recurso a peritos, ver as opiniões dissidentes dos Juízes Al-Khasawneh e Simma, e do Juiz ad hoc Vinuesa, a declaração do Juiz Yusuf e as opiniões separadas dos Juizes Keith e Cançado Trindade.

${ }^{13}$ Cfr. parágrafo 228 do acórdão. Para uma crítica deste aspecto ver opinião dissidente do Juiz ad hoc Vinuesa.
} 
Apesar de o TIJ ter transcrito estas passagens do relatório no acórdão $0^{14}$, a verdade é que não retirou daí as devidas consequências. De facto, o TIJ limitou-se a afirmar que as quantidades de fósforo acrescentadas pela fábrica de Fray Bentos eram insignificantes em comparação com o nível global de fósforo proveniente de outras fontes. Sem contestar esta desproporção, relembramos que deve sempre verificar-se se determinado parâmetro atingiu ou não um nível crítico. Ora, o Rio Uruguai já sofria de problemas de eutrofização. Por essa razão, era provável que uma descarga de fósforo equivalente à de uma cidade de 65 mil habitantes desprovida de sistema de tratamento de águas residuais não fosse assim tão insignificante no caso concreto. A corroborar esta probabilidade está um episódio ocorrido em Fevereiro de 2009: a "explosão" de algas no Rio Uruguai caracterizada pelas Partes como um fenómeno de eutrofização sem precedentes. A Argentina argumentou que tal incidente resultou das descargas efectuadas pela fábrica de celulose. O Uruguai contestou a relação de causalidade estabelecida pela Argentina e avançou a hipótese de o episódio ter origem na afluência de turistas na época do Carnaval de Gualeguaychú e no correspondente aumento do volume de águas residuais ${ }^{15}$. De qualquer forma, ficou estabelecido que a fábrica Orion (Botnia) não adoptou quaisquer medidas para compensar as descargas de fósforo. Nessa medida, a fábrica de celulose não cumpriu umas das condições estabelecidas para a autorização do projecto (ver citações retiradas do relatório da DINAMA).

A terceira situação reporta-se à presença de nonilfenóis nas águas do Rio Uruguai. O TIJ considerou que não ficou provado que os nonilfenóis provinham da fábrica Orion (Botnia) com base num desmentido categórico realizado por um funcionário da fábrica de celulose segundo o qual a Orion (Botnia) não utilizava nonilfenóis nos procedimentos de fabrico e limpeza. A fiabilidade que o TIJ reconheceu ao depoimento do funcionário da fábrica de celulose revela uma certa ingenuidade, e é mesmo insólita tendo em conta: (i) que a Argentina apresentou um relatório científico que apontava para a existência de nonilfenóis nas águas do Rio Uruguai localizadas na zona de influência da fábrica; (ii) e que foi apresentada uma amostra de celulose proveniente da fábrica Orion (Botnia) que revelava a presença de nonilfenóis.

Ora, consideramos que os três casos apresentados ilustram bem a leveza com que foram apreciados os dados científicos apresentados pela Argentina. E a situação ainda se torna mais grave se acrescentarmos um outro aspecto: não obstante o facto de as Partes - Argentina e Uruguai - reconhecerem a necessidade de adoptar medidas de precaução, o TIJ preferiu não se pronunciar quanto à aplicação do princípio da precaução no caso concreto. De facto, a Argentina argumentou que o Estatuto consagrava uma aproximação precaucionária que implicava a inversão do ónus da prova. Desta forma, caberia ao Uruguai provar que o seu projecto não causaria danos ao ambiente. O TIJ não acolheu esta posição e perdeu a oportunidade de recorrer ao princípio da precaução como critério decisório num domínio em que existia incerteza científica.

\section{Obrigação de proceder a uma avaliação de impacte ambiental}

Um dos aspectos inovadores deste acórdão foi o reconhecimento da existência, no direito internacional geral, de uma obrigação de proceder a uma avaliação de impacte ambiental (AIA) sempre que a actividade industrial projectada seja susceptível de ter um impacto prejudicial significativo num contexto transfronteiriço, e em especial num recurso partilhado.

\footnotetext{
${ }^{14}$ Cfr. parágrafos 244 e 245 do acórdão.

${ }^{15}$ Para que o leitor possa perceber a subtileza envolvida nesta hipótese, informamos que os movimentos sociais na origem da acção intentada junto do TIJ contra o Uruguai tiveram origem na cidade de Gualeguaychú e nas suas imediações.
} 


\section{$\operatorname{RerCED\varrho ̋UA~}$

O TIJ considerou no entanto que o direito internacional não permite concretizar o âmbito e o conteúdo da $\mathrm{AIA}^{16}$. Cabe portanto a cada Estado determinar, no quadro da sua legislação nacional ou do processo de autorização do projecto, o conteúdo exacto da AIA, tendo em consideração a natureza e dimensão do projecto em causa e o seu impacto negativo provável sobre 0 ambiente, assim como exercer toda a diligência necessária quando proceda a tal avaliação ${ }^{17}$.

Todavia, a AIA deverá sempre preceder a concretização do projecto ${ }^{18}$. E uma vez concretizado o projecto, o Estado fica obrigado a uma vigilância contínua dos efeitos do projecto sobre o ambiente que poderá prolongar-se por toda a vida do mesmo se tal for necessário ${ }^{19}$.

Assim, apesar de o TIJ se ter limitado a declarar a violação das obrigações procedimentais por parte do Uruguai, o acórdão não deixa de ter um efeito útil: o Uruguai encontra-se expressamente obrigado a realizar o controlo e monitorização do funcionamento da fábrica de celulose $e^{20}$.

Para além disso, competia ao TIJ, no caso concreto, avaliar se o Uruguai exerceu toda a diligência necessária quando procedeu à AIA. Neste contexto, o TIJ debruçou-se sobre dois aspectos: a escolha do local de implantação do projecto e a consulta da população afectada. Relativamente à escolha do local de implantação da fábrica, o TIJ considerou que o Uruguai actuou com a diligência necessária na avaliação das localizações alternativas ${ }^{21}$. No que respeita à consulta do público, apesar da Argentina ter referido a aplicação da Convenção de Espoo (Convenção da Comissão Económica das Nações Unidas para a Europa sobre Avaliação de Impacte Ambiental num contexto Transfronteiriço), e da Convenção de Aahrus (Convenção da UNECE sobre Acesso à Informação, Participação do Público no Processo de Tomada de Decisão e Acesso à Justiça em Matéria de Ambiente), o tribunal considerou que não recaía sobre o Uruguai uma obrigação consulta pública. Contudo, ficou estabelecido que o Uruguai realizou efectivamente a consulta da população afectada.

Este acórdão demonstra assim que o TIJ se considera competente para apreciar a diligência com que se procede à AIA, apesar de rejeitar a competência para fixar o conteúdo e 0 âmbito da mesma. Consideramos todavia que o TIJ não teria cometido nenhuma imprudência se tivesse estabelecido alguns requisitos mínimos da AIA, designadamente a consulta dos cidadãos potencialmente afectados pelo projecto.

\footnotetext{
${ }^{16}$ Neste sentido, ver a obra de N. SADELEER, Environmental Principles: From Political Slogans to Legal Rules, Oxford, 2008, p. 86 e 87: "A large number of international conventions require EIAs in transboundary context. (...) Thus, uncertainty persists as to the essential components of this procedural obligation (independence of the author of the EIA, quantity and quality of the information, public participation, etc.)".

${ }^{17}$ Em Portugal, o diploma que disciplina o procedimento de AIA é o Decreto-Lei n.ํㅜ 197/2005, de 8 de Novembro, que realiza a terceira alteração ao Decreto-Lei $n .069 / 2000$, de 3 de Maio, transpondo parcialmente para a ordem jurídica interna a Directiva n. ${ }^{2003 / 35 / C E}$, do Parlamento Europeu e do Conselho, de 26 de Maio. Para um comentário do Decreto-Lei $n .069 / 2000$, consultar a obra de JOSÉ EDUARDO FIGUEIREDO DIAS, ALEXANDRA ARAGÃO e MARIA TOLEDO ROLLA, Regime Jurídico da Avaliação de Impacte Ambiental em Portugal: Comentário, Coimbra, CEDOUA, 2002. ${ }^{18}$ Cfr. parágrafo 205 do acórdão.

${ }^{19} \mathrm{Cfr}$. parágrafo 205 do acórdão.

${ }^{20}$ Cfr. parágrafos 266 e 281 do acórdão.

${ }^{21}$ O Juiz ad hoc Vinuesa declarou na sua opinião dissidente que não foi realizada uma adequada ponderação das localizações alternativas. No entendimento deste juiz, a localização da fábrica de celulose em Fray Bentos fundouse exclusivamente na proximidade das plantações de eucaliptos.
} 


\section{Conclusão}

Num caso que envolvia a necessidade de confrontar a protecção do ambiente e da saúde humana com o desenvolvimento económico, o TIJ penalizou o elo mais fraco e chegou mesmo a declarar que a pronúncia relativamente à poluição do ar, aos maus odores e ao ruído se encontrava fora da sua jurisdição.

Na verdade, o desfecho do caso começou a desenhar-se logo no momento em que o TIJ se recusou a adoptar as medidas conservatórias requeridas pela Argentina. Tratou-se de um comportamento que permitiu a criação de uma situação difícil de reverter: desmantelar uma fábrica que envolveu o investimento de milhões de euros e que emprega, directa ou indirectamente, milhares de pessoas.

Neste contexto, consideramos que a própria distinção entre obrigações procedimentais e obrigações materiais serviu sobretudo o propósito de tentar chegar a uma solução salomónica da controvérsia. Admitiu-se em favor da Argentina que o Uruguai desrespeitou as obrigações procedimentais do Estatuto. Em contrapartida, concluiu-se que a fábrica de celulose podia manter-se em funcionamento visto que as obrigações materiais não haviam sido violadas.

Todavia, como vimos acima, o TIJ não procedeu sequer a uma avaliação adequada do cumprimento das obrigações materiais. Por um lado, o TIJ não consentiu a aplicação do princípio da precaução, pelo que o ónus da prova recaiu sobre a parte que invocava os riscos ambientais - a Argentina - e não sobre o promotor dos projectos susceptíveis de originar riscos ambientais - o Uruguai. Por outro lado, limitou-se a invocar a falta de prova convincente por parte da Argentina e não recorreu ao mecanismo previsto no artigo 50. do ETIJ.

Na nossa opinião, a forma como o TIJ lidou com este caso poderá desincentivar os Estados de recorrer ao TIJ para resolver controvérsias envolvendo um elevado grau de complexidade científica.

No entanto, independentemente de todas as críticas, este acórdão não deixou de apresentar alguns avanços. Desde logo, a AIA passa a ser considerada como obrigação decorrente do direito internacional geral, sempre que a actividade industrial proposta possa ter impactos negativos transfronteiriços. Em segundo lugar, este acórdão vem também avisar que os Estados que pretendem realizar projectos que afectem recursos naturais partilhados terão de respeitar elevados níveis de diligência na prevenção de danos a esses recursos. Finalmente, o acórdão do TIJ teve como efeito útil a imposição duma obrigação de controlo e monitorização sobre o Uruguai. 